\title{
An Overview of Hazardous Waste Management in Nigeria
}

\author{
Aminu Sulaiman Zangina and *Ahmed Fate Ali \\ Department of Environmental Management, \\ Bayero University, Kano, \\ Nigeria \\ Email:ahmadpate@yahoo.co.uk
}

\begin{abstract}
Hazardous wastes are substances that are no longer needed and have no current or perceived value at a given time or place. Many of the materials used or produced in chemical processes possess hazardous properties. The key hazardous wastes sources include industrial, medical, and household wastes, and occur in solid, liquid, or gaseous states. These are wastes that are classified and/or have intrinsic or inbuilt chemical and physical distinctiveness of toxicity, ignitability, corrosivity, and reactivity. Managing hazardous wastes is of immense significance to human, economic, social and environmental health conditions. Hazardous wastes management practice in Nigeria is not in consonance with the best global practices. Many hazardous wastes are dumped indiscriminately, which constitutes hazard to the environment and posed public health concerns. This study analysed the strength, weaknesses, opportunities and threats of hazardous wastes management in Nigeria. There are various environmental regulations on hazardous wastes in the country, but implementation remains a challenge, as such there is need for more proactive measures to be taken towards sustainable solutions to the problems.
\end{abstract}

Keywords: hazardous wastes, solid waste, public health, SWOT analysis, Nigeria.

\section{INTRODUCTION}

There is no single acceptable definition of hazardous waste, as several organizations or countries define hazardous waste differently, but all geared toward a single goal. Wastes are considered hazardous when they exhibit one or more hazardous characteristics, which includes toxic, explosive, oxidizing, irritant, flammable, carcinogenic, as well as other damaging effects on human health and the environment (Kummer, 1999). Notwithstading, researchers have defined and classified hazardous wastes as a specific class of waste with intrinsic chemical and physical distinctiveness, such as toxicity, ignitability, corrosivity, carcinogenicity, or other properties (Gu et al., 2014). The major characteristic of these refuse is that, in a way, they are potentially dangerous to humans and the environment, principally, when handled, transported or disposed of in an insecure manner (White and Heckenberg, 2011). Another definition states that hazardous waste is any unnecessary or thrown-out material (excluding radioactive material) which, due to its physical, chemical or infectious properties can cause a considerable danger to human health or the environment when inappropriately treated, stored, transported, disposed of or if not managed well (Sergi, 2008). These could be either solid, liquid or gas. 
Sources of hazardous wastes include e-products, vehicles, clinical and medical products, fuel products (e.g., lubricating oil), gas exploration and extraction among others (Mmereki et al., 2016). In addition, households, small and medium businesses, farms, healthcare and construction sectors also produce hazardous wastes such as batteries, electrical equipment, healthcare waste, solvent-based paint, and sheep dip. (Li et al., 2015). Industrial hazardous wastes pose significant risk to the environment and public health (Naviaa and Bezama, 2008). Significant industrial hazardous wastes have to do with used oil, materials contaminated by oil and spent solvents (Thanh et al., 2010).

Another source is health-associated facilities such as hospitals, health care centres, research institutes, whose wastes may contain toxic hazardous chemicals, substances that are destructive to genes or radioactive, pathological waste, sharp objects (such as, needles, syringes, scalpels, knives and broken glass), infectious waste, bulk human blood and blood products. (Yan et al., 2011; Sartaj and Arabgol, 2015). Furthermore, household and domestic activities are also known to generate hazardous wastes due to the use of products that may contain certain hazardous substances or materials. Those substances include paints, cleaning chemicals, batteries, stains and varnishes, motor oil products, pesticides (Environmental Protection Agency (EPA) of Ireland, 2013), cosmetics, food preservatives and e-wastes.

More developed countries, such as USA and some European Union member states are the major generators of hazardous waste in the world (Samanlioglu, 2013). Nigeria is reported to be the highest generator of hazardous waste in Africa, which was put at 2,469,000 tons per annum (Akpan and Olukanni, 2020). However, the per capita generation of hazardous waste in Africa is put at $20.1 \mathrm{~kg} /$ person/annum. The management of hazardous wastes is of enormous significant due to its implications on the environment, socioeconomics and public health. In this paper, the management of hazardous wastes in Nigeria is considered in all stages from its sources through to its final disposal as a waste. This overview is to highlight the hazardous waste substances, their management practices and proffer solutions to the issues raised in managing hazardous waste in Nigeria.

\section{CATEGORIES OF HAZARDOUS WASTE}

\section{Designated Hazardous Wastes}

This category comprises of any waste that is specifically listed or designated as hazardous by different countries (Grasso et al., 2010). The United States Environmental Protection Agency (USEPA) revealed the following designated list of priority chemicals as hazardous wastes (USEPA, 2005):

- F-list: This list has to do with hazardous waste generated from non-specific point sources, that is, numerous processes in the industry that led to the generation of the wastes. Examples include solvents used in degreasing, sludge and metal treatment, wastewaters from metal industries and dioxin that contains chemicals.

- K-list: This list contains hazardous waste generated by particular industrial processes. Examples include chemical production, pesticide production, explosive manufacturing, etc.

- P and U lists: Discarded chemical products, off-specification chemicals, residue from the spillage of materials, and container residues make up this list. 


\section{Characteristic Waste}

Any waste that solely exhibit either one or more of the properties of ignitability (flammability), corrosivity, reactivity, and toxicity including mixtures, derived-from, and asgenerated wastes can be classed as hazardous wastes (USEPA, 2005; Grasso et al., 2010).

\section{PUBLIC HEALTH AND ENVIRONMENTAL IMPLICATIONS OF HAZARDOUS WASTE}

Hazardous wastes can harm the environment by polluting air, water and soil. Upon release into the environment, it exerts adverse effects on the biosphere. Health related issues of hazardous wastes have been reported to include the potentials of causing cancer, infections, irritations (mainly due to allergic response), mutations or other toxic or radioactive effects (Grasso et al., 2010). The health and environmental effects of these wastes are reliant on the concentration (doses), routes, and length of exposure. For instance, short-term health symptoms of hazardous waste exposure can include dizziness, headaches and nausea, while prolonged exposure can lead to cancers, disabilities or death, neurological acute symptoms, respiratory and digestive systems concern (Dongo et al., 2012; Fazzo et al., 2017).

\section{HAZARDOUS WASTES MANAGEMENT IN NIGERIA}

Hazardous waste management practice in Nigeria is not in consonance with the global best practices. According to Yusuf (2009) Nigeria is like a discarding ground for hazardous wastes, and poor-quality goods/products which form a major environmental and public health challenge. Open dumpsites, on land and in water bodies are the more pronounced practices of hazardous wastesdisposal than any option, including incineration. As the case in many less developed countries, lack of enough trained personnel, special hazardous wastes transport vehicles, special hazardous wastes drop-off centres are key challenges facing the sector in Nigeria. Concentration of hazardous waste would be classified as 'special waste' and as such would be subject to the Special Waste Regulations 1996 with its consequent regulation of storage, transport, handling and treatment (Yusuf, 2009). However, environmentally sound management of hazardous wastes in Nigeria is faced with multiple challenges that include: inadequate information and statistics on the quantity and sources of hazardous waste generated in the country (Ubachukwu et al., 2014); lack of public awareness on the nature of hazardous waste and the danger posed to public health and the environment (Uwagbale, 2016); lack of political will by the government to put in place and enforce adequate legislations to deal explicitly with the matter of hazardous waste management, and inadequate training and capacity building on the current trends in the area of hazardous waste management (Ngwuluka et al., 2011).

\section{MAJOR SOURCES OF HAZARDOUS WASTES IN NIGERIA}

The main sources of hazardous waste in Nigeria are highlighted in this section, many of which are not segregated at source and end up being co-disposed with municipal wastes in unregulated dumpsites.

Crude Oil Spillage: The major sources of hazardous materials in Nigeria environmental are petrochemical industries. From 1976-1996 alone, there were a total of 4,835 oil spills that resulted in a spill volume of about 2.3 million barrels of crude oil (Kalu, 2006; Uwagbale, 2016).

Gas Flaring: It has been estimated that the total emission of carbon dioxide $\left(\mathrm{CO}_{2}\right)$ from gas flaring in Nigeria amounts to about 35 million tons/year. It has been asserted that Nigeria flares the highest gas in the world. On average, the rate of gas flaring in Nigeria over the 
period 1970-1979 stood at $97 \%$, falling marginally to an average of $72 \%$ between $1990-2000$ (World Bank, 2001).

Electronic Waste: Electrical and electronic equipment (EEE) contains hazardous substances such as lead, mercury, beryllium, cadmium, and brominated flame-retardants that pose both human and environmental health threat. EEE generated in Nigeria stood at 1.1 million tons for 2010 (Ogungbuyi et al., 2012).

Household Hazardous Waste: Major household wastes include the following: household cleaners and adhesives, automotive products, materials for home maintenance and garden products. The remains of these products are either found to be fatal, toxic, caustic, corrosive, flammable, reactive, explosive, radioactive or a combination of these (Agamuthu, 2001; Uwagbale, 2016).

Mining Activities: Excessive and crude mining activities render farmlands and rivers to toxic chemicals such as cyanides, arsenic, lead, mercury and sulphur which pose danger to humans and the environment (Aremu et al., 2011). These mining activities result in huge quantity of hazardous waste generation. An example is the local communities in Zamfara State that use mercury amalgamation method in extracting gold, a degrading process that produces morass of hazardous waste. The State also suffers from the processing of lead-rich ore mined by artisans for gold extraction. It has been registered that monazite, pyrochlore and xenotime which are by-products of tin mining in the Jos Plateau are also radioactive (Uwagbale, 2016).

Medical Waste: Healthcare related activities in Nigeria generate a considerable amount of wastes that are considered hazardous, such as chemotherapeutic agents, radio nucleoside, mercury, anesthetic gas, corrosive and expired pharmaceuticals. Used needles, bloodstained cotton and expired drugs are categorized as hazardous medical wastes because they can be poisonous or toxic. For instance, in Abuja, the average waste generation in health facilities per day was found to be $2.78 \mathrm{~kg}$ of solid wastes and $26.5 \%$ of which are hazardous in nature (Bassey et al., 2006). A study by Awodele et al. (2016) revealed that medical wastes generated in Lagos range from $0.116-0561 \mathrm{~kg} / \mathrm{bed} / \mathrm{day}$, while total waste is about 215.56 $\mathrm{kg} /$ day. The generation rate is approximately $0.181 \mathrm{~kg} / \mathrm{bed} /$ day. Many of these are often not segregated at source and end up co-disposed with municipal wastes in unregulated dumpsites.

\section{LEGAL AND REGULATORY FRAMEWORK FOR HAZARDOUS WASTE MAMANEGMENT IN NIGERIA}

There are existing legislations and regulations guiding hazardous waste activities towards its effective management in Nigeria. These regulations come with different options of penalties ranging from fines to jail terms in extreme cases. These regulations are meant to minimize or stop hazardous waste generation as stated in the harmful Waste (Special Criminal Provision Etc) Act 1988. The Act was enacted with the specific objective of prohibiting the carrying, depositing and dumping of hazardous waste on any land, territorial waters and matters relating thereto. This Act is essentially a penal legislation. It is evident in Section 6 of the Act that provides a very severe sentence of life imprisonment and in addition the forfeiture of any aircraft, vehicle or land connected with or involved with the violation (Nwufu, 2010). Other legislations include the harmful Waste Act (Decree 42 of 1988) retained as Cap HI LFN 2004; Environmental Impact Assessment Act retained as Cap EI2 LFN 2004; Environmental Guidelines and Standards for the Petroleum Industry in 
Nigeria 2002; NESREA act 2007; Management of Hazardous Wastes. I. 15; Guidelines on Hazardous Chemicals Management; Guidelines on Pesticides Management; National Environmental (Mining and Processing of Coal, Ores and Industrial Minerals) Regulations, S. I. No. 31 of 2009: National Environmental (Electrical/Electronic Sector) Regulations, S. I. No. 23 of 2011 (Uwagbale, 2016). The challenge in Nigeria lies more on the enforcement of these acts.

\section{SWOT ANALYSIS FOR HAZARDOUS WASTES MANAGEMENT IN NIGERIA}

The strengths, weaknesses, opportunities and threats of hazardous waste management in Nigeria were analysed in this research and summarized in Table 1.

Table 1: SWOT Analysis for Hazardous Waste Management in Nigeria

\begin{tabular}{|c|c|}
\hline $\begin{array}{l}\text { Strengths } \\
\text { - } \\
\text { - } \\
\text { - } \\
\text { - Empreased awareness about hazardous wastes } \\
\text { - } \quad \text { Introduction of 'polluter pays' principle } \\
\text { - Improved waste collection }\end{array}$ & \begin{tabular}{ll} 
& \multicolumn{1}{c}{ Weaknesses } \\
- & Inadequate training on waste handling \\
- & Lack of proper hazardous waste recycling facilities \\
- & Non-compliance to set standards \\
- & Poor enforcement by authorities \\
- & Low budgeting on research
\end{tabular} \\
\hline \begin{tabular}{ll} 
& \multicolumn{1}{c}{ Opportunities } \\
- & Employment opportunities \\
- & Partnerships with multinationalbodies \\
- & Alternativesfor hazardous substances \\
- & Establishment of proper hazardous \\
treatment facilities
\end{tabular} & $\begin{array}{l}\text { - Whreats } \\
\text { - Widespread risks of pathogens, infections and } \\
\text { carcinogens } \\
\text { - Unplanned development in urban centers } \\
\text { - Inadequate waste segregation techniques } \\
\text { - Threats from gas flaring, crude oil spillage, e-waste. }\end{array}$ \\
\hline
\end{tabular}

Strengths: Of importance is the increase in awareness about waste and waste related issues, which has helped immensely in the pursuit of safer environment. Empoweringregulatory bodies like NESREA, and professional entities such as, Environmental Health Officers Registration Council of Nigeria (EHORECON) to oversee environmental health activities is encouraging. Regular waste collection in some areas serves as another important aspect of managing hazardous waste. Relative compliance to harmful waste act by stakeholders is another avenue explored. EIA enforcement in developmental projects in Nigeria would have positive impacts on the management of hazardous waste especially in the areas of collection and final disposal. Introduction of 'polluter pays' principle adopted by National Environmental Standards and Regulations Enforcement Agency (NESREA) has strengthened hazardous waste management systems in Nigeria.

Weaknesses: Inadequate training on waste handling, separation, and disposal are some of the factors bedeviling hazardous waste management in Nigeria, as in most cases, they are co-disposed along with other waste streams. Proper hazardous waste recycling, collection facilities are lacking, which is a significant negative factor. Similarly, non-compliance to set standards by industries and organizations and not adhering to international conventions are other issues bedeviling hazardous waste management in Nigeria. Inadequate enforcement by authorities concerned was observed in this study. Low budgeting on research and development on hazardous wastein Nigeria is registered as a troubling issue.

Opportunities: Creation of employment opportunities and improving the economy (waste to wealth conversion) will be a welcomed development. This will contribute to increase in employment and health improvement. Creation of partnership with other multinational and development agencies with regards to hazardous waste management in Nigeria will create 
positive impacts. Replacement of some hazardous substances in use (synthetic fertilizer, pesticides, and herbicides) with sustainable options is another opportunity to be explored as observed by this study. Proper hazardous waste management will lead to reduction in waste landfilled in municipal dumpsites. Establishment of proper hazardous waste treatment facilities should be enacted. This will lead to improvement in sound environmental management practices and consequently, reduction in the incidence of diseases and infections. Another opportunity to be explored is the reduction in tapping, exploitation, and exploration of raw materials for production purposes that leads to generation of hazardous waste.

Threats: Wide spread of pathogens, infections, diseases, carcinogenic tendencies, and eventually death can occur if hazardous waste is not properly handled. Population growth, which is directly proportional to waste generation is a threat to hazardous waste management. Unplanned development taking place in urban areas is key because it hinders hazardous waste management leading to bioaccumulation of toxic substances within the environment. The grossly inadequate waste segregation at sources is unsustainable and poses significant risk of pollution. Similarly, threats from crude oil spillage, gas flaring, electronic waste, household hazardous waste, medical and special waste are injurious to the environment and public health concerns.

\section{CONCLUSION AND RECOMMENDATIONS}

Hazardous waste generation in Nigeria and the way it is not properly managed, presents a challenge to the environmental components and public health. As such, there is need for it to be managed properly for a safer Nigerian environment. Waste minimization through source reduction, reuse, and recycling should be effectively implemented and encouraged in order to decrease the quantity of hazardous waste produced and disposed. Enforcement of various acts related to hazardous waste management in Nigeria should be encouraged, and relevant penalties should be exercised. Adoption of best available technology and integrated approach for effective and efficient handling of hazardous waste is highly recommended. Enactment of strict measures for industries and organizational non-compliance to set standards and international conventions is encouraged. Establishment of hazardous waste treatment facilities and substitution of hazardous substances with less toxic or non-toxic ones is also recommended. However, hazardous waste segregation techniques should be explored for a sustainable management. It is imperative that all stakeholders ranging from policy makers, regulators, product producers, generators and handlers of hazardous waste play vital roles in making sure that such materials are managed sustainably. They should be avoided or prevented, where necessary, minimized, collected, and treated properly and disposed using best practices.

\section{REFERENCES}

Agamuthu, P. (2001). Solid Waste: Principles and Management. Institute of Biological Sciences, University of Malaya.

Akpan,V. E. and Olukanni, D. O. (2020). Hazardous Waste Management: An African Overview. Recycling.5(15): 1-24.

Aremu, M. O. Ozonyia, G. N. and Ikokoh, P. P. (2011). Electronic journal of Environmental Agricultural and Food Chemistry. 10 (6): 2296-2304.

Awodele, O., Adewoye, A.A. and Oparah, A.C. (2016). Assessment of medical waste management in seven hospitals in Lagos, Nigeria. BMC Public Health 16: 269. 
Bassey, B.E., Benka-Coker, M.O. and Aluyi, H.S. (2006). Characterization and management of solid medical wastes in the Federal Capital Territory, Abuja Nigeria. African Health Sciences. 6(1): 58-63.

Dongo, K., Tiembré, I., Koné, B. A., Zurbrugg, C., Odermatt, P., Tanner, M., Zinsstag, J. and Cisse, G. (2012). Exposure to toxic waste containing high concentrations of hydrogen sulphide illegally dumped in Abidjan, Cote d'Ivoire. Environmental Science and Pollution Research. 19(8):3192-9.

Environmental Protection Agency of Ireland (2013) Proposed Revised National Hazardous Waste Management Plan. Summary Document. Available at: http://www.epa.ie/pubs/

reports/waste/haz/Proposed\%20Revised\%20NHWMP\%20Summary.pdf Accessed on 5-9-2020.

Fazzo, L., Minichilli, F., Santoro, M., Ceccarini, A., Della Seta, M., Bianchi, F., Comba, P. and Martuzzi, M. (2017). Hazardous waste and health impact: a systematic review of the scientific literature. Environmental Health, 16:107.

Grasso, D., Kahn, D., Kaseva, M. E. and Mbuligwe, S. E. (2010). Hzardous Waste Management. Encyclopedia of Life Support Systems (EOLSS)-UNESCO Sample Chapters.

Gu, B., Zhu, W., Wang, H., Zhang, R., Liu, M., Chen, Y., Wu, Y., Yang, X., He, S., Cheng, R., Yang, J. and Bi, J. (2014). Household Hazardous Waste Quantification, Characterization and Management in China's Cities: A Case Study of Suzhou. Waste Management. 34 (11): 2414-2423.

Kalu, V. E. (2006). Toxic Wastes and The Nigerian Environment: an appraisal. Department of Private \& Property Law University of Benin, Benin City. 2006.

Kummer, K. (1999) International Management of Hazardous Wastes: The Basel Convention and Related Legal Rules. Oxford University Press. Great Britain.

Li, L., Wang, S., Lin, Y., Liu, W. and Chi, T. (2015). A covering model application on Chinese industrial hazardous waste management based on integer program method. Ecological Indicators, 51, 237-243.

Mmereki, D., Baldwin, A., Hong, L. and Li, B. (2016). The Management of Hazardous Waste in Developing Countries. Creative common, 39-51.

Naviaa, R. and Bezama, A. (2008). Hazardous waste management in Chilean main industry: An overview. Journal of Hazardous Materials, 158: 177-184.

Ngwuluka, N. C., Ochekpe, N. A. and Odumosu, P. O. (2011). An assessment of pharmaceutical waste management in some Nigerian pharmaceutical industries. African Journal of Biotechnology, 10(54): 11259-11264.

Nwufu, C. C. (2010) Legal Framework for the Regulation of Waste in Nigeria. African Research Review: An International Multi-Disciplinary Journal, Ethiopia, 4(2): 491-501.

Ogungbuyi, O., Nnorom, I. C., Osibanjo, O. and Schluep, M. (2012). E-Waste Country Assessment Nigeria. E-waste Africa Project of the Secretariat of the Basel Convention, May 2012.

Samanlioglu, F. (2013). A multi-objective mathematical model for the industrial hazardous waste location-routing problem. European Journal of Operational Research. 226: 332-340.

Sartaj, M. and Arabgol, R. (2015). Assessment of healthcare waste management practices and associated problems in Isfahan Province (Iran). Journal of Material Cycles and Waste Management, 17(1): 99-106.

Sergi, S. (2008) Hazardous Waste Strategy 2006-2010. Environment Protection Authority (EPA South Australia). 
Thanh, N.P., Matsui, Y. and Fujiwara, T. (2010). Household solid waste generation and characteristic in a Mekong Delta city, Vietnam. Environmental Management. 91: 23072321.

Ubachukwu, N. N., Phil-Eze, P. O. and Emeribe, C. N. (2014). Analysis of Household Hazardous Wastes Awareness Level in Enugu Metropolis. Academic Journal of Interdisciplinary Studies. 3(1): 369-377.

United States Environmental Protection Agency (2005). Introduction to Hazardous Waste Identification. Solid Waste and Emergency Response. 1-26.

Uwagbale, E. D. (2016) Hazardous Waste Management and Challenges in Nigeria. Public Health International, 1(1): 1-5.

White, R. and Heckenberg, D. (2011). What is Hazardous Waste and What makes it Hazardous? Briefing Paper No 2. School of Sociology and Social Work, University of Tasmania. 1-28.

World Bank (2001). World Development Report, 2000/2001. Industry and Energy Operations Division (West Central Africa Department). Washington D. C.

Yan, M., Li, X.D., Lu, S.Y., Chen, T., Chi, Y. and Yan, J.H. (2011). Persistent organic pollutant emissions from medical waste incinerators in China. Journal of Material Cycles and Waste, 13: 213-218.

Yusuf, T. A. (2009). Trafficking and Dangerous Disposal of Hazardous Wastes in Nigeria: Tackling the Root Cause. Retrieved from https://www.inigerian.com/traffickingand-dangerous-disposal-of-hazardous-wastes-in-nigeria-tackling-the-root-cause/ on 14-7-2018. 